\title{
STATE OF THE ART IN TRANSLATION TEACHING AND RESEARCH IN BRAZIL ${ }^{1}$
}

\author{
Maria Candida Bordenave
}

\begin{abstract}
Convinced that translation in the present-day world is one of the most efficient ways to make science, the arts, philosophy, knowledge, activities. cosmovisions and culture universal, and even more convinced that a good translation will preserve our language which is our patrimony and worthy of our efforts, we the undersigned plead publishers in Brazil to be careful in selecting capable professionals, well known for their command of both the source and target languages, so that by merely reading the translated texts, we shall preserve the most important characteristics of our century-old literary tradition, and which has shaped and consolidated our cultural language worldwide and demographically in seven countries in the American, European and Asian continents.
\end{abstract}

The above statement is taken from a document issued by the Brazilian Academy of Letters in support of the Brazilian Translators Association's movement to recognize the profession in the Ministry of Labour.

There are two reasons why translation should be considered a vital area in Brazilian history: the fact that Portuguese is the national language and Brazil's level of social and economic development.

The first reason isolates Brazil linguistically. In spite of the fact that some 157 million people in seven countries in three continents speak the language, these figures are not matched by a similarly high intellectual output. In this sense our Portuguesespeaking interlocutors are numerically limited.

On the other hand, our present levels of economic, technological, scientific and cultural development and consolidation require a solid input of translated works periodicals, articles, books and papers from diverse areas - that facilitate scientific, technological, philosophical and artistic progress, thereby allowing for great qualitative steps forward in research and intellectual production. No country is an island therefore translation is a two-way road that allows mankind to integrate the world's cultural, scientific movements.

It was not until the end of the sixties that translationbecame a college coursefor professional training. Before that, translators were lettered men and women, mostly writers, who, at a given moment in time, felt compelled to uncover the mysteries of translation.

\footnotetext{
${ }^{1}$ N.E.: Publicado em META, v. 35, n. 3, Les Presses de l’Université de Montreal, 1990.
} 
From the sixties on. as decreed by the Ministry of Education, Departments of Letters, which basically trained language teachers, were able to broaden their scope and, with minor changes in their curriculum, offer new courses on the university level to train translators. As time went on, after careful and constant analysis and evaluation of the results, these courses departed from the initial model, which closely adhered to the teacher training program, and began to gain independence in the search for a new curriculum better suited to the real professional needs of the students.

The first courses were created at universities: the Catholic University of Rio de Janeiro (PUC/RJ). the Catholic University of Rio Grande do Sul (PUC/RS), and the Federal University of Rio Grande do Sul (UFRS). Then twelve other courses were established in different parts of the country, and at present they have become prestigious courses with well-structured programs and a well-trained teaching staff.

One of the signs the field of translation in Brazil "has come of age" is the fact that related activities that go beyond teaching and learning have come forth, attesting to an expansion of knowledge and experience of a field which suddenly gained academic stature. We are referring to research activities - studies, papers, theses and dissertations - congresses and meetings between professors and researchers, specialized journals, etc., a true hallmark of translation's vitality.

Last year, ANPOLL (National Association of Research and Graduate Studies in Letters and Linguistics) set up a work group on translation, whose members presentedand discussed their papers at the II National Congress in May of last year. The III National Congress will be held from May 17 to 20 this year, with a round-table discussion on the theme "Research in Translation". The second part of the program includes discussion of the following items:

- setting up a journal to exchange and disseminate studies, news and book reviews by national and foreign authors in the field of translation:

- creation of a National Association of Professors and Researchers of Translation and Terminology.

The publication of university periodicals which are partially or fully devoted to the field of translation is also proof of translation's vitality in Brazil. In addition to Tradução e Comunicação, first published in December 1981 by Alamo Publishers in conjunction with the Ibero-American School in São Paulo, issue number 17 of Ilha do Desterro, published in 1987 by the English Department of the Federal University of 
Santa Catarina, and Trabalhos de Línguística Aplicada, published by UNICAMP (Campinas State University), are devoted exclusively to articles on translation. Other university journals have published articles on translation, such as the Anais da $4^{\circ}$ Semana de Estudos Germânicos, published by the Federal University of Minas Gerais, and Com TextosNo. 1, 1987, Federal University of Ouro Preto.

It is also worth mentioning that several congresses and meetings have reinforced and stimulated the exchange of ideas and research in the field of translation. We are referring specifically to the I and II National Meeting on Translation held at PUC/RJ and the III National Meeting held at the Federal University of Rio Grande do Sul, which centralized all the papers and discussions on translation teaching.

At other national or regional congresses and meetings there have been sessions for the presentation of papers on translation, either under the linguistic, the literary or the methodological approach. The first National Congress of Applied Linguistics, held in July 1986 at the State University of Campinas (UNICAMP), and the VII ERPULI (Regional Meeting of University Professors of English), held in August 1986 at the Catholic University of Rio de Janeiro (PUC/RJ), had sessions with papers on translation, and the International Congress of Letters, with the theme "Language, Discourse and Ideology”, held in September 1987 at the Federal University of Rio de Janeiro (UFRJ), scheduled the following round table: "Language and Ideology within the Context of Translation”.

Another important fact that points to the growth of translation area in Brazil is the number of courses given on teacher training for this field.

The need for good translators has led universities in many regions in Brazil to plan and offer translation training courses for their own foreign language professors, taught by the specialized staff from Rio de Janeiro and São Paulo universities. These are called specialization courses, and are aimed at translators interested in training in the main subjects necessary for translation teaching. Their duration is 360 class-hours. In 1988, two such courses will be held in northern Brazil:at the Federal University of Amazonas and the Federal University of Maranhão, taught respectively by the staff of the University of São Paulo (USP) and the Catholic University of Rio de Janeiro (PUC/RJ).

At the Catholic University of Rio de Janeiro there are presently two research projects on translation being developed under the sponsorship of CNPq (National 
Council for Research), a government agency which provides funds for academic research.

The first is in the field of the theory of translation and is being carried out by Prof. Maria Paula Frota. It attempts to bring together theoretical constructs from different areas of knowledge, in an effort to achieve an interdisciplinary theoretical study of translation. From the many definitions available of the concept of natural language, reflexions are made on the real meaning of interlingual differences and the concepts of translatability and fidelity. One of the basic tenets of this study is the firm belief that translation, as an area of human knowledge, should resort to other knowledge available from diverse fields such as anthropology, history, philosophy of language, and sociolinguistics. Professor Frota attempts to make this theoretical meeting of the disciplines explicit.

The second project focuses on the questionof a specific methodology for the teaching of translation, being developed by the author. The general research scheme is broad and covers linguistic, semantic and pragmatic aspects on the one hand, and cultural and ideological on the other, all within atheoretical framework of knowledge and the mental operations inherent to translation.

After making a diagnosis of the mistakes most frequently made by students in specific areas - for example, gesture verbs like “nod” and "shrug”, "frown” for which there is no exact one-verb equivalent in Portuguese - we proceeded to do a linguistic, semantic, pragmatic and semiotic analysis of the data.

Another study underway in the same project line is entitled "Error Typology in Translation Practice”. It has a wider spectrum and attempts a diagnosis of the students' mastery by analysing the main errors committed by the students from one class in their translation exercises - 300 pages — during one school term.

The third aspect of translation with which the author has been working is related to the theoretical framework based on B. Bloom's categories, which is efforttoanalyse and describe the mental processes going on in the translator's mind while at work. In this study, the goal has been to open the black box of the translation process to identify the main stages and operations which will be the basis for an adequateteaching methodology.

What was said above are all signs of the seething vitality and drive in translation teaching and research all over the country, which express a not-so-subtle change of 
BORDENAVE - State of the art in translation teaching...

status of the area within academia and which also point to a qualitative improvement in translation, as well as to a stronger position for the translator's profession and status in the country's cultural life. 